\title{
A KÉSEI MEGGY (PRUNUS SEROTINA EHRH.) ELŐFORDULÁSÁNAK VIZSGÁLATA A NAGYLÓZSI FAFAJ-ÖSSZEHASONLÍTÓ KÍSÉRLET TERÜLETÉN
}

\author{
Nemes Viktória, Csiszár Ágnes és Bartha Dénes \\ Soproni Egyetem, Erdömérnöki Kar, Növénytani és Természetvédelmi Intézet
}

\begin{abstract}
Kivonat
Vizsgálatunk során a Győr-Moson-Sopron megyei Nagylózs $5 \mathrm{~F}$ kísérleti célú erdőrészlet tizenkét parcellájában végeztünk cönológiai felmérést. Kutatásunk fő célkitűzése az inváziós kései meggy előfordulásának vizsgálata volt az 1969-ben telepített, különböző célállományú parcellákban. Megfigyeléseink szerint a kései meggy az erdőrészlet minden parcellájában jelen van, de a környező erdörészletekben is nagymértékü terjedést mutat. A faj a szelídgesztenye, lucfenyő és erdeifenyő célállományú parcellák lombkoronaszintjében dominánssá vált, azonban e parcellákra mindegyikére jellemző az ültetett fafaj jelentős visszaszorulása. A magas záródású hársas állományokban csak elenyésző borítással, többnyire csak csíranövény állapotban fordult elö. A statisztikai elemzés a lombkorona záródása és a kései meggy cserjeszintbeli borítása között negatív korrelációt mutatott ki. Vizsgálataink alapján a faj terjedésének megakadályozásakor javasolt kiemelt figyelmet fordítani a zárt erdőbelső, valamint a második, árnyaló lombkoronaszint megőrzésére.
\end{abstract}

Kulcsszavak: kései meggy, fafaj-összehasonlító kísérlet, lombkorona záródás

\section{STUDIES ON BLACK CHERRY (PRUNUS SEROTINA EHRH.) OCCURRENCE IN THE AREA OF COMPARATIVE TREE SPECIES EXAMINATION, NAGYLÓZS}

\begin{abstract}
Coenological studies have been carried out in Nagylózs 5F experimental forest subcompartment (Györ-Moson-Sopron county) to examine the occurrence of invasive black cherry in different forest stands planted in 1969. According to our monitoring results, black cherry is present in all parcels of the forest subcompartment and shows considerable spreading in the surrounding areas. Among the 12 studied parcels, the species became dominant in the canopy layer of sweet chestnut, Norway spruces and Scots pine parcels; where the presence of the former planted trees had decreased considerably. It occurs only infinitesimally, mainly with seedlings in linden parcels with high canopy closure. Statistical analyses confirmed negative correlation between the canopy closure and black cherry dominance in shrub layer. According to our studies, we would like to draw the attention to the importance of canopy closure and shading effect of the second canopy layer during the control of black cherry.
\end{abstract}

Keywords: black cherry, comparative tree species examination, canopy closure 


\section{BEVEZETÉS}

Az észak-amerikai származású kései meggy (Prunus serotina Ehrh.) Európa szerte elterjedt inváziós fafaj, jelentősebb állományai hazánkon kívül Németországban és Belgiumban találhatók, föként tápanyagszegény homoktalajokon (Starfinger 1990, 1997, Muys \& Maddelein 1992, Kowarik 2010). Hazánkban számos termőhelyen, valamint különböző élőhelyeken, kultúrerdőktől a természetközeli élőhelyeken át megjelenik, elöfordulásának súlypontja azonban a homokvidékekre tehető (Nyírség, Kiskunság, Belső-Somogy). Terjedését telepítésén kívül spontán terjedése és a termőhely bolygatása is elősegíti (Juhász 2004, 2008, 2012, Juhász \& Bagi 2008). Növekedés- és fejlődésgátló allelopátiás hatását laboratóriumi és szabadföldi vizsgálatok is igazolják (Robakowski \& Bielinis 2011, Nagy 2012, Csiszár et al 2012, 2013). Fiatalkori gyors növekedése, hatékony biomassza-allokációja és magas asszimilációs rátája kompetíciós előnyt biztosít számára számos fafajjal, többek között a kocsánytalan tölggyel (Quercus petraea (Matt.) Liebl.) szemben (Robakowski et al 2018). Terjedését a herbivorok számára potenciálisan mérgező ciánglikozid tartalma is elősegítheti, ennek ellenére a gímszarvas (Cervus elaphus L.) néha megrágja. Sürü állományai a nagyvad számára jó vadbúvóhelyet biztosítanak. A magok terjesztésében kiemelt szerepe van a termését fogyasztó madaraknak, amelyek mozgását és ezáltal a magterjesztés távolságát jelentősen meghatározzák a pihenő- és éjszakázóhelyek jelenléte, valamint a tájszerkezet (Deckers et al 2005, 2008, Kurek et al 2015).

A kései meggy hatása a természetes vegetációra rendkivül sokrétü, allelopátiás és kompetíciós hatásán túl az avar- és humuszképződés felgyorsitása által megváltoztatja a termőhelyet, fokozatosan átalakítja az állomány cserjeszintjét, majd alsó lombkoronaszintjét, végül erős árnyalásával a gyepszintjét is (Juhász 2004, 2012). A kései meggy hatását az erdőállomány gyepszintjére számos vizsgálat kutatta, melyek többsége a gyepszint fajgazdagsáságnak csökkenését mutatta ki (Godefroid et al 2005, Verheyen et al 2007, Vanhellemont et al 2011, Halarewicz \& Zolnierz 2014). A különböző termőhelyü, fafajú és kezelésủ állományokban azonban a hatás jelentős eltéréseket mutathat (Halarewicz \& Zolnierz 2014). A természetvédelmi problémák mellett a kései meggy jelentős erdőgazdálkodási problémát is okoz, mind a fatermesztés célú intenzív erdőművelésben, mind a természetes felújulás terén (Kowarik 2010, Juhász 2012, Nagy 2012). Kertészeti jelentősége a gyümölcsfajainkat kárositó olyan idegenhonos rovarfajok terjesztésében nyilvánul meg, mint például a keleti cseresznyelégy (Rhagoletis cingulata Loew) vagy a pettyesszárnyú muslica (Drosophila suzukii Matsumura) (Szeőke 2007, Tuba et al 2012, Kiss et al 2016, Poyet et al 2014). Visszaszorítását megnehezíti intenzív tősarjképző képessége, irtására a mechanikai módszerek közül a magoncok kihúzása és a fák kéreggyürüzése sikerrel alkalmazható; vegyszeres irtása esetén vastag bőrnemü levelei miatt tapadássegítő szerek alkalmazása javasolt (Csiszár \& Korda 2017, Demeter \& Lesku 2017, Nemes et al 2017, Vadász 2017, Verö \& Csóka 2017).

A szakirodalmi ismeretek szerint a kései meggy számos, különböző szerkezetủ és összetételü erdőállományban képes terjedni (Juhász 2004, 2008, 2012, Juhász \& Bagi 2008). A nagylózsi fafaj hasonlító kísérlet lehetőséget biztosított arra, hogy a faj terjedését azonos termőhelyi körülmények között, különböző célállományú mintaparcellákban vizsgálhassuk. A kései meggy előfordulásának vizsgálatával arra a kérdésre kerestük a választ, hogy van-e összefüggés az egyes állományok szerkezete és a kései meggy terjedésének mértéke között.

\section{ANYAG ÉS MÓDSZER}

Vizsgálatainkat a Sopron-Vasi-síkság Ikva-Répce-síkján elhelyezkedő Nagylózs 5F erdőrészletben kijelölt mintaterületeken végeztük (1. ábra). A Nagylózs $5 \mathrm{~F}$ erdörészlet 8,64 hektáros területén 1969-ben az Erdészeti és Faipari Egyetem Erdőműveléstani Tanszéke által, Dr. Majer Antal professzor irányítása alatt 33 mintaparcellán összesen 17 különböző fafaj ültetésére került sor, fafaj-összehasonlitó kísérlet céljából. Kísérletük célja 
az volt, hogy ismereteket gyüjtsenek arról, hogy néhány hazai elegy- és idegenhonos fafaj milyen növekedést mutat a mintaterülethez hasonló éghajlati és termőhelyi körülmények között. A terület talajképző kőzete a hajdani Ős-Rába teraszát alkotó kavics és az arra rárakódott lösz, melyen rozsdabarna cseri talaj alakult ki (Kondorné Szenkovics 2007a). A vizsgálati terület a zárt tölgyes és gyertyános tölgyes klímaöv határán helyezkedik el, ahol a természetes erdőtársulás gyertyános-kocsánytalan tölgyes és cseres-kocsánytalan tölgyes közötti átmeneti jellegü (Querco petraeae - Carpineum, ill. Quercetum petreae-cerris) Galium odoratum, illetve Festuca heterophylla erdőtípussal (Majer 1980). Az erdőrészletben alkalmazott erdészeti beavatkozások közül az ápolási munkákon túl megemlítendő az 1987-ben és 1989-ben végzett, összes parcellát érintő tisztítás, illetve 2001-ben az erdőrészlet teljes területén végzett törzskiválasztó gyérítés (Kondorné Szenkovics 2007b). 2005-ben a lucfenyő fafajú parcellában egészségügyi fakitermelést, 2006-ban a vörös tölgy, kocsánytalan tölgy, erdeifenyő, duglászfenyő, nyugati ostorfa, kislevelü és nagylevelü hárs fafajú parcellákban törzskiválasztó gyérítést hajtottak végre (Fenyősy 2016). Különböző abiotikus és biotikus károk következtében az eredetileg kijelölt 33 parcella közül 5 parcella célállománya jelentősen károsodott vagy elpusztult, a 28. parcellába ültetett kései meggy állományt letermelték és kivették a kísérletből.

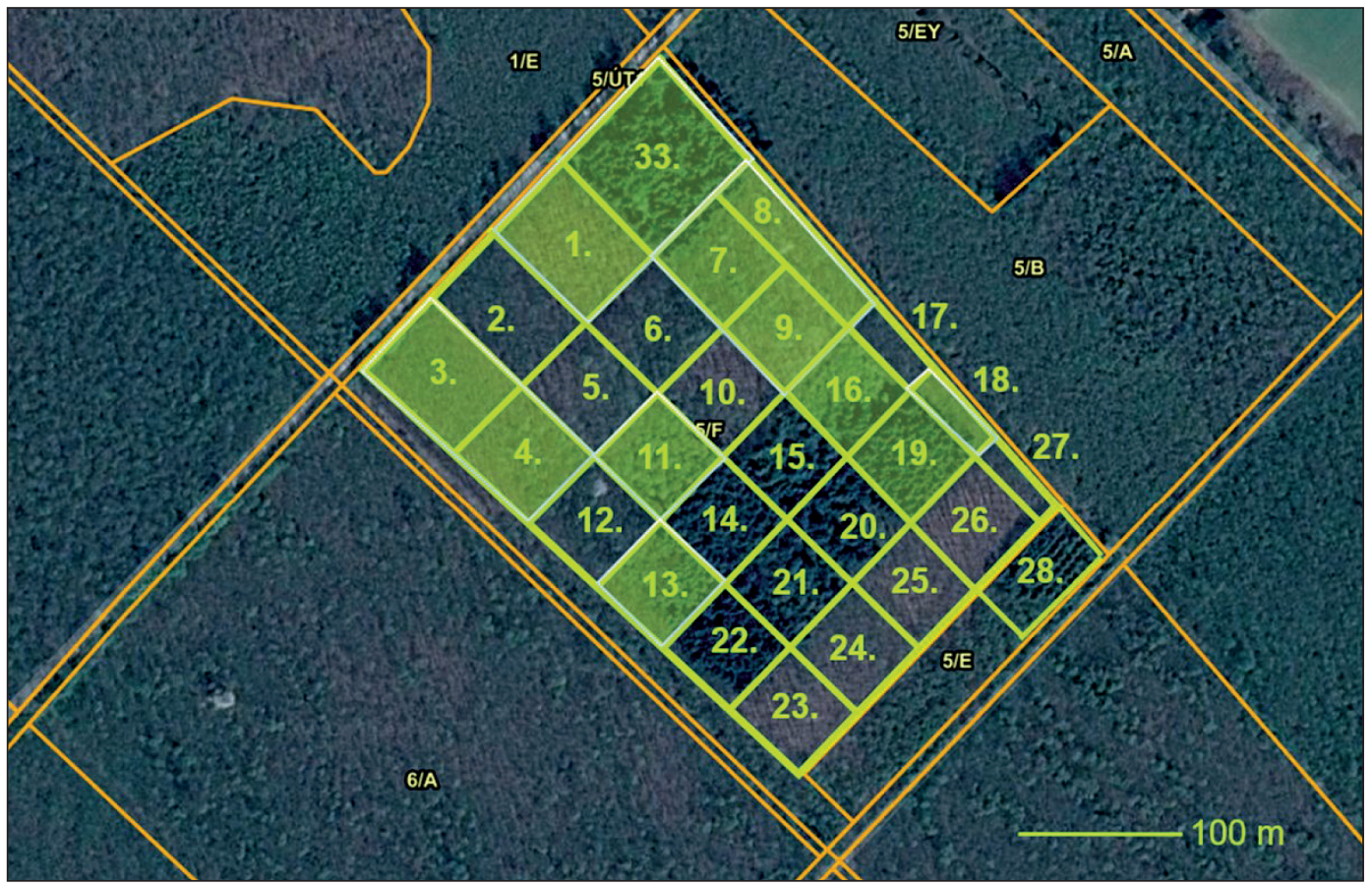

1. ábra: A fafaj-összehasonlító kisérlet során kialakitott parcellák elhelyezkedése a Nagylózs 5F erdőrészletben, zöld színnel jelölve a vizsgálatra kiválasztott parcellák (http://erdoterkep.nebih.gov.hu/)

Jelmagyarázat: A parcellák célállományai: vörös tölgy:1., 2., 10., 23., 24., 25., 26.; nyugati ostorfa: 3.; nagylevelü hárs: 4., 6.; ezüst hárs: 5., 9.; kislevelü hárs: 7., 12.; kocsánytalan tölgy 8., 17.; szelídgesztenye: 11; erdeifenyő: 13.; feketefenyő: 14.; himalájai selyemfenyő 15.; közönséges lucfenyő 16.; kocsányos tölgy: 18., 27.; zöld duglászfenyő: 19., 22.; kék duglászfenyő: 20., 21.; lucfenyő - zöld duglászfenyő: 33.; kései meggy: 28; nemesnyár: 29., 30., 31., 32.

Figure 1: Location of comparative tree examination parcels in Nagylózs 5F forest subcompartments, studied parcels highlighted with green colour

Abbreviations: Planted tree species in parcels: Quercus rubra: 1., 2., 10., 23., 24., 25., 26.; Celtis occidentalis: 3.; Tilia platyphyllos: 4.,6.; Tilia tomentosa: 5., 9.; Tilia cordata: 7., 12.; Quercus petraea: 8., 17.; Castanea sativa: 11; Pinus sylvestris: 13.; Pinus nigra:

14.; Pinus wallichiana: 15.; Picea abies 16.; Quercus robur: 18., 27.; Pseudotsuga menziesii var. viridis: 19., 22.; Pseudotsuga menziesii var. glauca: 20., 21.; Picea abies - Pseudotsuga menziesii var. viridis: 33.; Prunus serotina: 28;

Populus x euramericana: 29., 30., 31., 32. 
A kései meggy terjedésének vizsgálata céljából, a Nagylózs $5 \mathrm{~F}$ erdőrészletben, előzetes terepi bejárás alapján összesen 12, különböző célállományú parcellát választottunk ki, amelyek megegyeztek a fafaj-összehasonlító kísérlet során kialakított parcellákkal (1. ábra). Az eredetileg kialakított 17 különböző célállomány közül vizsgálatunkból kizártuk azokat, amelyek parcelláit megszüntették (letermelték és kivonták a vizsgálatból, pl. nemesnyár) vagy azon nem az üzemtervben meghatározott célállomány fordult elő. Az azonos fafajú parcellák esetén egyet jelöltünk ki. Vizsgálataink során feltételeztük, hogy a kései meggy propagulumai, az azt terjesztő madarak közvetítése által az erdőrészlet területén belül közel egyidőben, közel egyforma mennyiségben egységesen eljutottak. Felméréseink során mindegyik parcellában három darab, $20 \mathrm{~m} \times 20 \mathrm{~m}$ nagyságú kvadrátot jelöltünk ki, amelyben 2017 tavaszán és nyarán cönológiai felvételt készítettünk. A parcellákban rögzítettük a lombkoronaszint és a cserjeszint záródását, a gyepszint és mohaszint boritását, a szintenként előforduló növényfajok borítását (lombkorona esetén záródását), valamint a kései meggy borítását és magasságát. A parcellák sorszáma, az ültetett fafaj, a lombkorona- és a cserjeszint záródása, a gyepszint boritása, valamint a parcellákban megjelenő kései meggy föbb jellemzői az 1. táblázatban láthatók.

\section{1. táblázat: A vizsgált parcellák növényzetének föbb jellemzői \\ Megjegyzés:*Az érték a felső lombkoronaszint záródására vonatkozik \\ Table 1: General botanical data of studied parcels}

Abbreviations: ${ }^{1}$ number of parcels, ${ }^{2}$ tree species, ${ }^{3}$ average cover, ${ }^{4}$ black cherry, ${ }^{5}$ average height, ${ }^{6}$ tree layer, ${ }^{7}$ shrub layer, ${ }^{8}$ herb layer,

*The value shows the closure of upper canopy layer

\begin{tabular}{|c|c|c|c|c|c|c|c|c|c|c|}
\hline \multirow{3}{*}{ 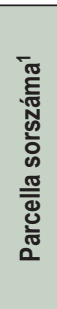 } & \multirow[b]{3}{*}{ Ültetett fafaj ${ }^{2}$} & \multirow{2}{*}{\multicolumn{3}{|c|}{$\begin{array}{c}\text { Átlagos záródás I } \\
\text { borítás }(\%)^{3}\end{array}$}} & \multicolumn{6}{|c|}{ Kései meggy ${ }^{4}$} \\
\hline & & & & & \multicolumn{3}{|c|}{ átlagborítása $(\%)^{3}$} & \multicolumn{3}{|c|}{ átlagmagassága $(\mathrm{m})^{5}$} \\
\hline & & 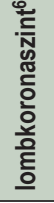 & 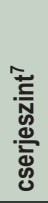 & 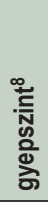 & 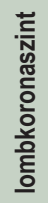 & 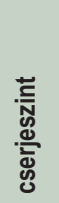 & $\begin{array}{l}\text { 䓂 } \\
\text { o. } \\
\text { à̃ }\end{array}$ & 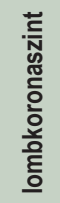 & 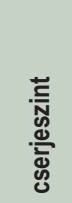 & 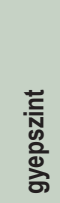 \\
\hline 1. & vörös tölgy & 92 & 75 & 20 & 0 & 69 & 5 & 0 & 3,33 & 0,40 \\
\hline 3. & nyugati ostorfa & 91 & 78 & 65 & 0 & 75 & 7 & 0 & 4,50 & 0,53 \\
\hline 4. & nagylevelű hárs & 97 & 0 & 2 & 0 & 0 & 0 & 0 & 0 & 0,13 \\
\hline 7. & kislevelủ hárs & 98 & 0 & 3 & 0 & 0 & 0 & 0 & 0 & 0,10 \\
\hline 8. & kocsánytalan tölgy & 84 & 73 & 17 & 0 & 73 & 7 & 0 & 3,33 & 0,53 \\
\hline 9. & ezüst hárs & 98 & 1 & 6 & 0 & 1 & 3 & 0 & 1,33 & 0,50 \\
\hline 11. & szelídgesztenye & 76 & 38 & 68 & 73 & 38 & 12 & 8 & 2,17 & 1,10 \\
\hline 13. & erdeifenyő & $53^{*}$ & 0 & 1 & 95 & 0 & 0 & 8 & 0 & 0,50 \\
\hline 16. & $\begin{array}{l}\text { közönséges } \\
\text { lucfenyő }\end{array}$ & 98 & 0 & 2 & 98 & 0 & 1 & 8 & 0 & 0,05 \\
\hline 18. & kocsányos tölgy & 70 & 93 & 0 & 0 & 93 & 0 & 0 & 4,67 & 0,37 \\
\hline 19. & zöld duglászfenyő & 91 & 0 & 4 & 0 & 0 & 1 & 0 & 0,53 & 0,43 \\
\hline 33. & \begin{tabular}{|l} 
lucfenyő - zöld \\
duglászfenyő
\end{tabular} & 94 & 12 & 20 & 3 & 12 & 4 & 2,33 & 1,67 & 0,33 \\
\hline
\end{tabular}

A növényfajok nevezéktana az Új Magyar Füvészkönyvet (Király 2009) követi, a záródási és boritási viszonyokat százalékos értékben határoztuk meg. Az adatok elemzésekor a fajok tavaszi és nyári boritási értekei közül a magasabb értékkel számoltunk, a parcellákra jellemző átlagértékek meghatározásakor a három kvadrát adataiból képeztünk átlagot. Az eredmények statisztikai kiértékelését nem paraméteres varianciaanalízissel (Friedman teszt, Dunn teszt) és Spearman féle rangkorrelációval végeztük $(P<0,05)$ (INSTAT 2003). 


\section{EREDMÉNYEK ÉS MEGVITATÁSUK}

Az 5F erdőrészletben és terepi megfigyeléseink szerint a környező erdőrészletekben is a kései meggy tömeges jelenlétét tapasztaltuk. A cönológiai felvételek alapján a kései meggy az összes vizsgált parcellában megjelent, a kislevelű és a nagylevelű hárs fafajú parcella esetén azonban a kései meggy borításának három kvadrátból képzett átlaga nem érte el az egy százalékot (2. ábra). A kései meggy borítása kimagasló a szelídgesztenye (Castanea sativa Mill.), lucfenyő (Picea abies (L.) H. Karst.) és erdeifenyő (Pinus sylvestris L.) célállományú parcellákban, ezek mindegyikére jellemző az ültetett fafaj jelentős visszaszorulása, záródásának csökkenése (3. ábra). A lucfenyő és a szelídgesztenye célállományú parcellákban a lombkoronaszintet gyakorlatilag a kései meggy alkotja, ez utóbbiban az ültetett szelídgesztenye már csak néhány egyeddel képviseli magát. Az erdeifenyő célállományú parcella alsó lombkorona szintjében a kései meggy csaknem teljes záródású, felette az erdeifenyő és a fehér akác (Robinia pseudoacacia L.) alkot laza felső szintet. A vizsgált parcellák lombkoronaszintjét tekintve a más területről betelepülő őshonos fajok közül mindössze a madárcseresznye (Cerasus avium (L.) Moench) fordul elő néhány egyeddel, helyenként viszont megfigyelhető a fehér akác terjedése. A parcellák cserjeszintje a magas záródású állományok többségénél hiányzik, a többi parcellában pedig szinte csak a kései meggy alkotja. A faj jelenléte különösen meghatározó a vöröstölgy (Quercus rubra L.), nyugati ostorfa (Celtis occidentalis L.), szelídgesztenye, kocsányos és kocsánytalan tölgy (Quercus robur L., Q. petraea) parcellák cserjeszintjében. A kései meggyen kívül csak a vöröstölgy és a nyugati ostorfa fordul elő az azonos célállományú parcellák cserjeszintjében, jelentéktelen záródással. A gyepszintben a kései meggy borítása egyik parcellában sem jelentős, számos helyen csak csíranövényei vannak jelen. Az ültetett fafajok magoncain kívül a madárcseresznye, mezei juhar (Acer campestre L.), közönséges gyertyán (Carpinus betulus L.), csertölgy (Quercus cerris L.), vadkörte (Pyrus pyraster (L.) Burgsd.) és a fehér akác jelenik meg a gyepszintben néhány egyeddel. Jelentős viszont a nyugati ostorfa újulata, amely nagyobb egyedszámban még csak az ostorfa célállományú parcellában fordul elő.

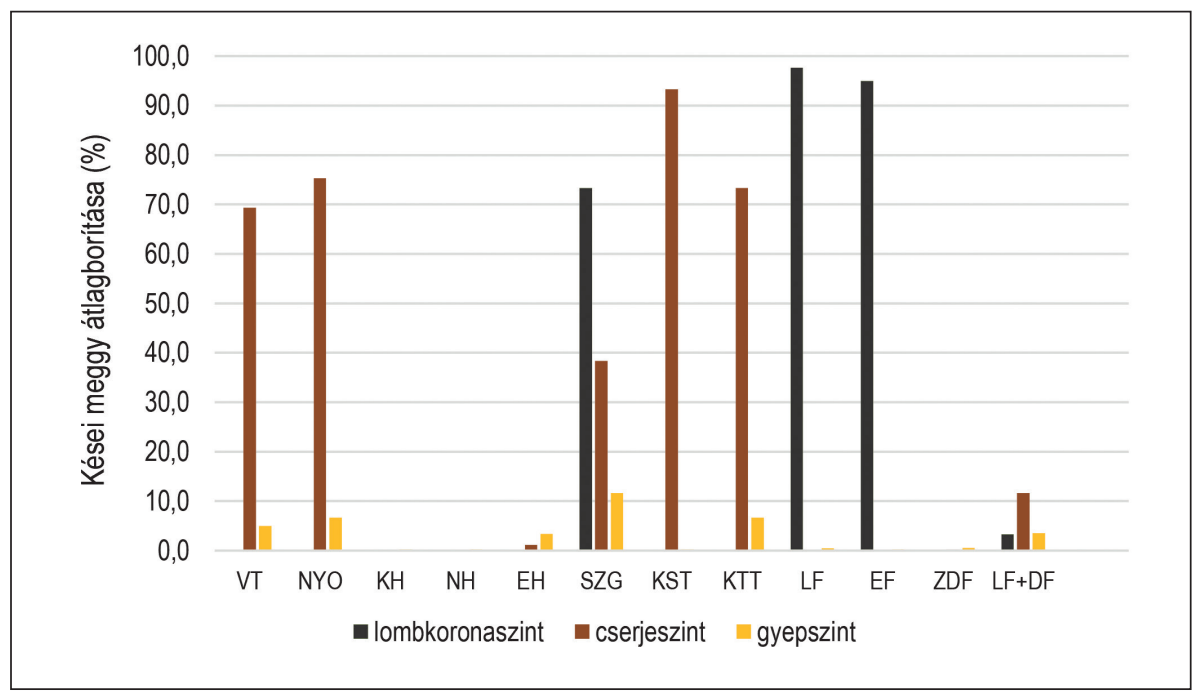

2. ábra: A kései meggy átlagos boritása a különböző célállományú parcellákban

Jelmagyarázat: VT: vörös tölgy, NYO: nyugati ostorfa, KH: kislevelű hárs, NH: nagylevelü hárs, EH: ezüst hárs, SZG: szelídgesztenye, KST: kocsányos tölgy, KTT: kocsánytalan tölgy, LF: közönséges lucfenyő, EF: erdeifenyő, ZDF: zöld duglászfenyő,

LF+ZDF: lucfenyő - zöld duglászfenyő

Figure 2: Average cover of black cherry in parcels of different main tree species

Abbreviations: VT: Quercus rubra, NYO: Celtis occidentalis, KH: Tilia cordata, NH: Tilia platyphyllos, EH: Tilia tomentosa, SZG: Castanea sativa, KST: Quercus robur, KTT: Quercus petraea, LF: Picea abies, EF: Pinus sylvestris, ZDF: Pseudotsuga menziesii

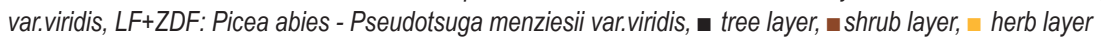




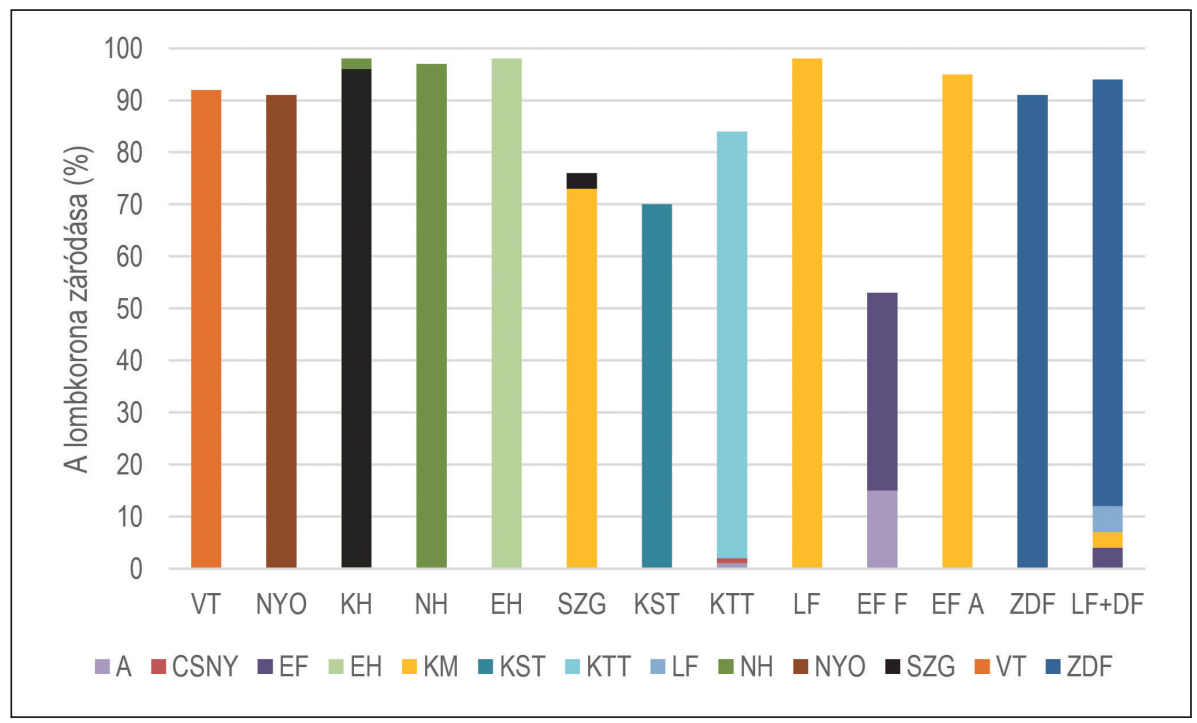

3. ábra: A lombkorona záródása és összetétele a különböző célállományú parcellákban

Jelmagyarázat: VT: vörös tölgy, NYO: nyugati ostorfa, KH: kislevelü hárs, NH: nagylevelü hárs, EH: ezüst hárs, SZG: szelídgesztenye, KST: kocsányos tölgy, KTT: kocsánytalan tölgy, LF: közönséges lucfenyő, EF: erdeifenyő, F: felső lombkoronaszint, A: alsó lombkoronaszint, ZDF: zöld duglászfenyő, LF+ZDF: lucfenyő - zöld duglászfenyö, A: fehér akác, CSNY: madárcseresznye, KM: kései meggy

Figure 3: Canopy closure and species composition of tree layers in parcels

Abbreviations: VT: Quercus rubra, NYO: Celtis occidentalis, KH: Tilia cordata, NH: Tilia palthyphyllos, EH: Tilia tomentosa, SZG: Castanea sativa, KST: Quercus robur, KTT: Quercus petraea, LF: Picea abies, EF: Pinus sylvestris, F: canopy layer, A: sub-canopy layer, ZDF: Pseudotsuga menziesii var.viridis, LF+ZDF: Picea abies- Pseudotsuga menziesii var.viridis, A: Robinia pseudoacacia, CSNY: Cerasus avium, KM: Prunus serotina

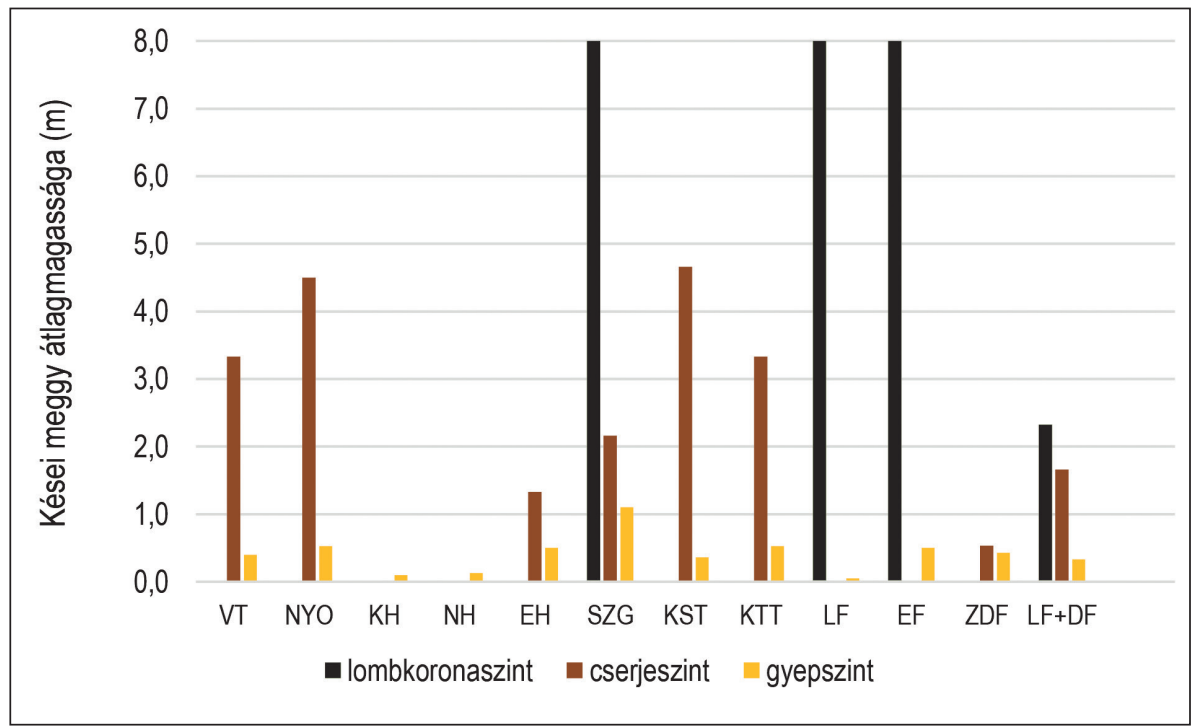

4. ábra: A kései meggy átlagmagassága a különböző fafajú parcellákban Jelmagyarázat: a fafajok kódja a 2. ábra alatt látható Figure 4: Average height of black cherry in parcels Abbreviations: see Figure 2. 
A kései meggy magassága a lombkoronaszintben a szelídgesztenye, luc- és erdeifenyő célállományú parcellákban, és a parcellákon belüli kvadrátokban is egységes képet mutat; 8 méter körül alakul (4. ábra). A luc- és zöld duglászfenyő célállományú parcellában a kései meggy csupán az egyik, alacsonyabb záródású kvadrátban jelent meg, hét méteres magassággal. A parcellák többségének cserjeszintjében a kései meggy magassága három és öt méter közötti értéket vesz fel, a kocsányos tölgy és ostorfa célállományú parcellákban magassága megközelíti a lombkoronaszintet. A gyepszintben a faj általában alacsony borítású és magassága is csak ritkán éri el az egy métert.

A vizsgált parcellák mindegyike egy erdőrészletben található a kései meggy terjedési forrásául szolgáló 28. parcellával, így a parcellák távolsága feltételezhetően nem befolyásolta a kései meggy megtelepedésének és terjedésének sikerét (1. ábra). A kései meggy terjedését befolyásoló tényezők vizsgálata céljából a lombkorona záródásának mértékét korreláltattuk a kései meggy cserjeszintbeli boritásával. Az elemzésből kizártuk azokat a parcellákat, amelyek lombkoronaszintjében jelen volt a kései meggy. A Spearman féle rangkorreláció szignifikáns negatív korrelációt mutatott ki a lombkorona záródása és a kései meggy cserjeszintbeli záródása $(r=-0,7287 ; P<0,0001)$, illetve magassága $(r=-0,6856 ; P=0,0002)$ között (5-6. ábra).

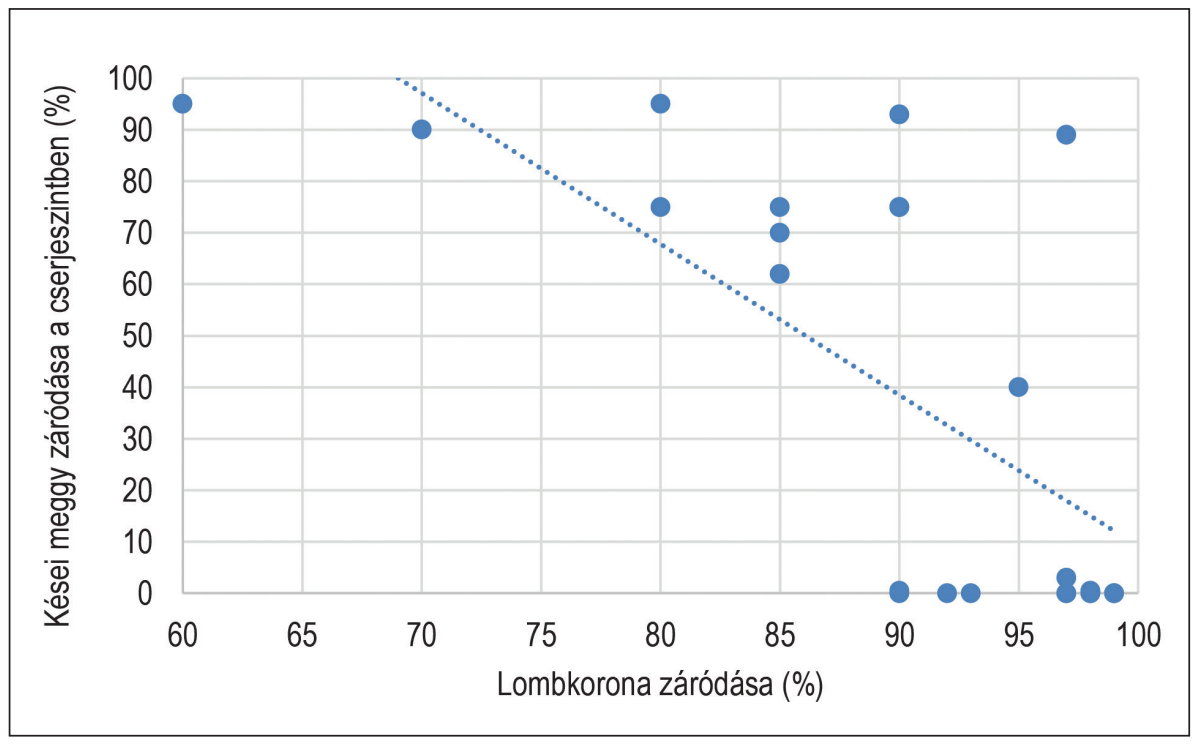

5. ábra: A lombkorona záródásának és a kései meggy cserjeszintbeli záródásának összefüggése Figure 5: Correlation between canopy closure and black cherry closure in shrub layer 


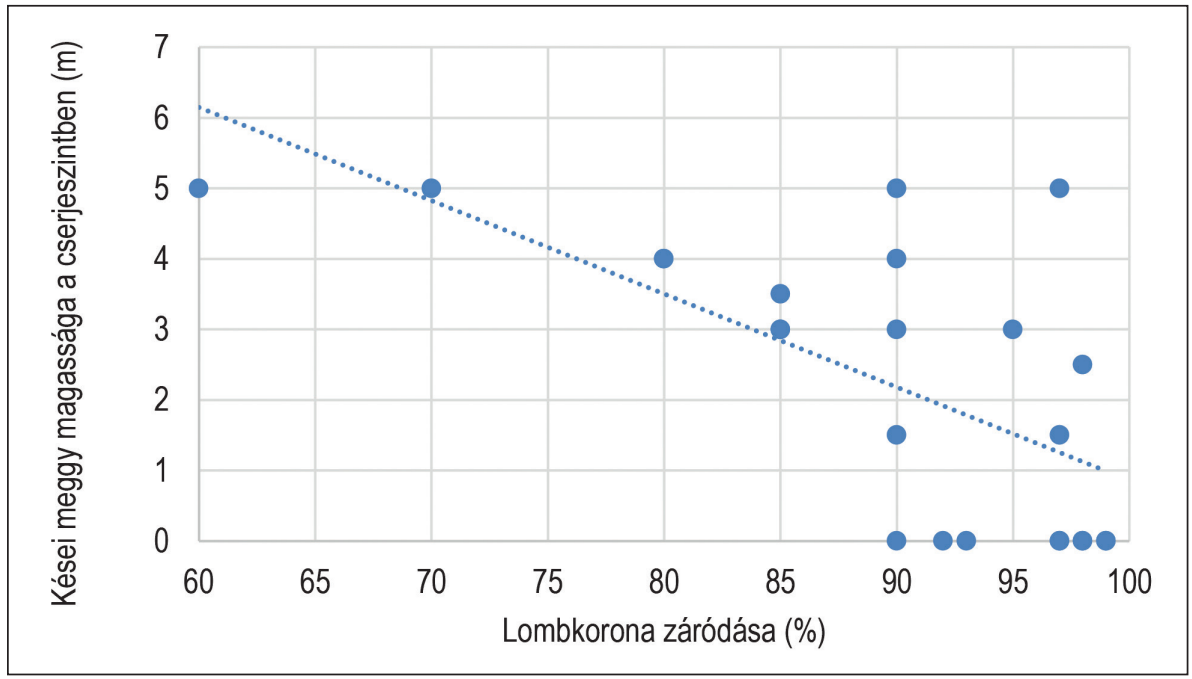

6. ábra: A lombkorona záródásának és a kései meggy cserjeszintbeli átlagmagasságának összefüggése

Figure 6: Correlation between canopy closure and average height of black cherry in shrub layer

\section{ÖSSZEFOGLALÁS}

A közel ötven éve létrehozott fafaj összehasonlító kísérlet számos, többek között termőhelyi és faterméstani kutatás alapjául szolgált (Kondorné Szenkovics 2007a, Fenyősy 2016). A mintaterületen létrehozott, majd később megszüntetett kései meggy parcella a fafaj termőhelyi igényeinek, növekedésének, fejlődésének tanulmányozásán túl (Kondorné Szenkovics 2007a) lehetővé tette terjedési képességének vizsgálatát is. Kondorné Szenkovics Mariann (2007a) faállomány-szerkezeti kutatásai szerint a kései meggy növekedése a kedvező termőhelyi adottságoknak köszönhetően már az ültetést követő tizedik évben is a legjelentősebbek közé tartozott, és kiemelkedő növekedési rátáját 35 éves korára is megőrizte. A faj gyors növekedése és fejlődése azonban elősegítette terjedését is, így napjainkban a kései meggy kisebbnagyobb tömegességgel az erdőrészlet minden parcellájában jelen van, de terepi megfigyelésink alapján a környező erdőrészletekben is nagymértékü terjedést mutat. Kutatásunk során tizenkét, különböző célállományú parcellában vizsgáltuk a kései meggy előfordulását, összefüggést keresve az állomány szerkezete és a faj terjedésének mértéke között. A kései meggy az összes vizsgált parcellában elöfordult, de kiemelten magas borítást ért el azokban a parcellákban, ahol az ültetett fafajok jelentősen visszaszorultak. A szelídgesztenye, a lucfenyő, valamint az erdeifenyő célállományú parcellák lombkoronaszintjében a kései meggy monodominánssá vált. A magas záródású hársas állományokban a kései meggy csak elenyésző boritással és gyakran csak csíranövény állapotban volt jelen. A lombkorona záródásának szerepét a kései meggy terjedésében a statisztikai elemzés is alátámasztotta, a lombkorona záródása és a kései meggy cserjeszintbeli záródása közötti negatív korrelációt mutatott ki. Eredményeink alátámasztják a korábbi szakirodalmi ismereteket, melyek szerint a faj növekedése fényszegény körülmények között, zárt erdőbelsőben gátolt, azonban az egyedek ilyen esetben is sokáig túlélhetnek (Juhász 2004). Godefroid és munkatársai (2005) azt tapasztalták, hogy a csíranövények fényigényesebbek, a csemeték azonban később árnyéktürőbbé válnak, majd kedvezőbb fényviszonyok esetén gyors növekedésnek indulnak. Ez a stratégia elősegitheti a faj robbanásszerü terjedését, hiszen "magoncbankot” képezve gyorsan tud reagálni a kedvezővé váló fényviszonyokra. Mindez felhívja a figyelmet a zárt erdőbelső és a második, árnyaló lombkoronaszint megőrzésének fontosságára. 


\section{KÖSZÖNETNYILVÁNÍTÁS}

A publikáció a „Soproni Egyetem Struktúraváltási Terve” - 32388-2/2017 INTFIN sz. projekt keretében az Emberi Erőforrások Minisztériuma támogatásával valósult meg.

\section{FELHASZNÁLT IRODALOM}

Csiszár Á. \& Korda M. 2017: Inváziós növényfajok visszaszoritásával kapcsolatos kezelési kísérletek összefoglalása. In: Csiszár Á. \& Korda M. (eds): Özönnövények visszaszorításának gyakorlati tapasztalatai. Duna-lpoly Nemzeti Park Igazgatóság, Budapest, 215-216.

Csiszár Á., Korda M., Schmidt D., Šporčić D., Süle P., Teleki B., Tiborcz V., Zagyvai G. \& Bartha D. 2013: Allelopathic potential of some invasive neophytes occurring in Hungary. Allelopathy Journal 31(2): 309-318.

Csiszár Á., Korda M., Schmidt D., Šporčić D., Teleki B., Tiborcz V., Zagyvai G. \& Bartha D. 2012: Néhány inváziós és potenciálisan inváziós neofiton allelopátiás hatásának vizsgálata. Botanikai Közlemények 99(1-2): 159-171.

Deckers B., Verheyen K., Hermy M. \& Muys B. 2005: Effects of landscape structure on the invasive spread of black cherry Prunus serotina in an agricultural landscape in Flanders, Belgium. Ecography 28: 99-109. DOI: 10.1111/j.09067590.2005.04054.x

Deckers B., Verheyen K., Vanhellenmont M., Maddens E., Muys B. \& Hermy M. 2008: Impact of avian frugivores on dispersal and recruitment of the invasive Prunus serotina in an agricultural landscape. Biological Invasions 10: 717727. DOI: $10.1007 / \mathrm{s} 10530-007-9164-3$

Demeter L. \& Lesku B. 2017: Özönnövények irtása a Hortobágyi Nemzeti Park Igazgatóság dél-nyírségi területein. In: Csiszár Á. \& Korda M. (eds): Özönnövények visszaszorításának gyakorlati tapasztalatai. Duna-Ipoly Nemzeti Park Igazgatóság, Budapest, 79-85.

Fenyősy A. 2016: A Nagylózs 5F erdőrészletben létesített fafaj-összehasonlitó kísérlet értékelése. Diplomamunka, NyugatMagyarországi Egyetem, Erdőmérnöki Kar, Erdőművelési és Erdővédelmi Intézet, Sopron, 72 pp.

Godefroid S., Phartyal S. S., Weyembergh G. \& Koedam N. 2005: Ecological factors controlling the abundance of nonnative invasive black cherry (Prunus serotina) in deciduous forest understory in Belgium. Forest Ecology and Management 210: 91-105. DOI: 10.1016/j.foreco.2005.02.024

Halarewicz A. \& Żołnierz L. 2014: Changes in the understorey of mixed coniferous forest plant communities dominated by the American black cherry (Prunus serotina Ehrh.). Forest Ecology and Management 313: 91-97. DOI:10.1016/j. foreco.2013.11.006

InStat 2003: GraphPad InStat, Version 3.06, for Windows, GraphPad Software, Inc., San Diego.

Juhász K. M. \& Bagi I. 2008: A Prunus serotina Ehr. élöhely preferenciái az invázió diszperziós szakaszában homoki területeken. Botanikai Közlemények 94(1-2): 1-16.

Juhász M. 2004: Kései meggy. In: Mihály B. \& Botta-Dukát Z. (eds): Özönnövények. TermészetBúVÁR Alapítvány Kiadó, Budapest, 273-292.

Juhász M. 2008: Black cherry (Prunus serotina Ehrh.). In: Botta-Dukát Z. \& Balogh L. (eds): The most important Invasive Plants in Hungary. HAS Institute of Ecology and Botany, Vácrátót, 77-84.

Juhász M. 2012: Kései meggy (Prunus serotina). In: Csiszár Á. (ed): Inváziós növényfajok Magyarországon. Nyugat-magyarországi Egyetem Kiadó, Sopron, 95-100.

Király G. (ed) 2009: Új Magyar Füvészkönyv - Magyarország hajtásos növényei. I. kötet, Határozókulcsok. Aggteleki Nemzeti Park Igazgatóság, Jósvafő, 616 pp.

Kiss B., Kis A. \& Kákai Á. 2016: The rapid invasion of spotted wing drosophila, Drosophila suzukii (Matsumura) (Diptera: Drosophilidae), in Hungary. Phytoparasitica 44: 429-433. DOI: 10.1007/s12600-016-0520-7

Kondorné Szenkovits M. 2007a: Fafaj-összehasonlító kísérletek értékelése. Doktori értekezés, Nyugat-Magyarországi Egyetem, Sopron, $238 \mathrm{pp}$.

Kondorné Szenkovits M. 2007b: A 35 éves Nagylózsi (Soproni-dombvidék) fafajösszehasonlító kísérlet tapasztalatai. Erdészeti Lapok 142(2): 40-42. 
Kowarik I. 2010: Biologische Invasionen. Neophyten und Neozoen in Mitteleuropa. 2. Aufl., Verlag Eugen Ulmer, Stuttgart, $492 \mathrm{pp}$.

Kurek, P., Sparks, T. H. \& Tryjanowski, P. 2015: Electricity Pylons May Be Potential Foci for The Invasion Of Black Cherry Prunus Serotina In Intensive Farmland. Acta Oecologica 62: 40-44. DOI: 10.1016/j.actao.2014.11.005

Majer A. 1980: Vizsgálati eredmények a fafajmegválasztás köréböl. Erdészeti és Faipari Tudományos Közlemények: $55-64$.

Muys, B. \& Maddelein, D. 1992: Ecology, practice and policy of black cherry (Prunus serotina Ehrh.) management in Belgium. Silva Gandavensis 57: 28-45. DOI: 10.21825/sg.v57i0.885

Nagy A. 2012: Az akác és a kései meggy. Erdészeti Lapok 147(2): 37.

Nemes V. E., Molnár M. \& Csiszár Á. 2017: A kései meggy (Prunus serotina) sarjak növekedési ütemének vizsgálata erdőfelújitásban és zárt állomány alatt. VI. Kari Tudományos Konferencia kiadványa, Soproni Egyetem Kiadó, Sopron, 227-229.

Poyet M., Eslin P., Héraude M., Le Roux V., Prévost G., Gibert P. et al. 2014: Invasive host for invasive pest: when the Asiatic cherry fly (Drosophila suzukii) meets the American black cherry (Prunus serotina) in Europe. Agricultural and Forest Entomology 16: 251-259 pp. DOI: 10.1111/afe.12052

Robakowski P. \& Bielinis E. 2011: Competition between sessile oak (Quercus petraea) and black cherry (Padus serotina): dynamics of seedlings growth. Polish Journal of Ecology 59(2): 297-306.

Robakowski P., Bielinis E. \& Sendall K. 2018: Light energy partitioning, photosynthetic efficiency and biomass allocation in invasive Prunus serotina and native Quercus petraea in relation to light environment, competition and allelopathy. Journal of Plant Research 131: 505-523. DOI: 10.1007/s10265-018-1009-x

Starfinger U. 1990: Die Einbürgerung der Spätblühenden Traubenkirsche (Prunus serotina Ehrh.) in Mitteleuropa. Landschaftsentwicklung und Umweltforschung 69: 1-119.

Starfinger U. 1997: Introduction and naturalization of Prunus serotina in Central Europe. In: Brock J. H., Wade M., Pysek P., Green D. (eds): Plant Invasions: Studies from North America and Europe. Backhuys Publishers, Leiden, The Netherlands, 161-171.

Szeőke K. 2007: Cseresznyelégy Amerikából. AgroNapló 11(4): 69-70.

Tuba K., Schuler H., Stauffer C. \& Lakatos F. 2012: A nyugati dióburok-fúrólégy (Rhagoletis completa Cresson 1929 Diptera: Tephritidae) megjelenése Magyarországon. Növényvédelem 48 (9): 419-424.

Vadász Cs. 2017: Az inváziós növényfajok visszaszorításának tapasztalatai a Felső-kiskunsági Turjánvidéken. In: Csiszár Á. \& Korda M. (eds): Özönnövények visszaszoritásának gyakorlati tapasztalatai. Duna-Ipoly Nemzeti Park Igazgatóság, Budapest, 181-189.

Vanhellenmont M., Baeten L., Verbeeck H., Hermy M. \& Verheyen K. 2011: Long-term scenarios of the invasive black cherry in pine-oak forest: Impact of regeneration success. Acta Oecologica 37: 203-211. DOI: 10.1016/j.actao.2011.02.003

Verheyen K., Vanhellenmont M., Stock T. \& Hermy M. 2007: Predicting patterns of invasion by black cherry (Prunus serotina Ehrh.) in Flanders (Belgium) and its impact on the forest understorey community. Diversity and Distributions 13: 487-497. DOI: 10.1111/j.1472-4642.2007.00334.x

Verő Gy. \& Csóka A. 2017: Özönnövény kezelési tapasztalatok a nagykőrösi pusztai tölgyesekben és a Turjánvidéken. In: Csiszár Á. \& Korda M. (eds): Özönnövények visszaszorításának gyakorlati tapasztalatai. Duna-Ipoly Nemzeti Park Igazgatóság, Budapest, 191-199.

Érkezett: 2018. április 12.

Közlésre elfogadva: 2018. augusztus 25. 